\title{
Effects of nutrition and environmental factors on the fetal programming of the reproductive axis*
}

\author{
Stewart M. Rhind ${ }^{1}$, Michael T. Rae ${ }^{1}$ and A. Nigel Brooks ${ }^{2}$ \\ ${ }^{1}$ Macaulay Land Use Research Institute, Craigiebuckler, Aberdeen AB15 8QH, UK; \\ and ${ }^{2}$ AstraZeneca, Cancer and Infection Bioscience, Alderley Park, Macclesfield, \\ Cheshire SK10 4TG, UK
}

\begin{abstract}
Research from a wide range of scientific disciplines has shown that the reproductive performance of animals in adult life is determined, in part, by a variety of extraneous influences acting at different stages of development from before conception until after birth. These effects are probably mediated through changes in the hypothalamic-pituitary and gonadal axes but the physiological system that is affected depends on the stage of development at which the influence is applied. The physiological mechanisms through which environmental influences are transmitted to the target organs are, in many cases, complex and poorly understood. Gonadotrophins seem to play a pivotal role in the development of the fetal testis, although effects of environmental influences on $\mathrm{GnRH}$ secretion have yet to be demonstrated. Other studies have shown that, at earlier stages of fetal development, the normal ontogeny of gonadal development and function can be disrupted by undernutrition or the influence of endocrine-disrupting compounds. Specifically, in female fetuses, the onset of meiosis is delayed, whereas, in male fetuses, testosterone synthesis is increased as a result of enhanced testicular steroidogenic enzyme activity. Although reproductive performance is clearly influenced by prenatal factors, much further work is required to identify the relationships between developmental abnormalities and adult reproductive function. Work is also required to elucidate further the critical windows in development and the mechanisms by which environmental factors affect the reproductive organs of developing offspring.
\end{abstract}

Effects of recent or current nutrition and of environmental factors on the reproductive performance of many species have been recognized for at least a century, and this knowledge has probably been applied to the rearing of domestic species for thousands of years, to maximize production. However, it is only in recent decades that the importance of prenatal and early postnatal factors, particularly nutrition, in the programming of reproductive function appears to have been recognized (Gunn et al., 1972; Gunn, 1977; Allden, 1979). One reason for the relatively recent recognition of this effect is the fact that studies of such phenomena require relatively long-term, controlled experimental conditions to ensure that changes in reproductive capacity programmed into the developing fetus are not masked by the effects of other environmental influences, to which they may be exposed later, or by compensatory changes in physiology, which may also occur at a later stage.

Email: s.rhind@mluri.sari.ac.uk

*This article is based on a presentation given at the British Society of Animal Science symposium 'Early Regulation of Mammalian Development' held in Aberdeen in September 2000.
Such studies have been conducted by Gunn and coworkers, using the sheep as an experimental model, to show that undernutrition during early stages of development, either before or after birth, can induce a reduction in the lifetime reproductive capacity of the female offspring (Gunn et al., 1995; Rhind et al., 1998a). This work has stimulated more detailed studies of the underlying mechanisms and is probably one reason for the high frequency with which sheep have been used in such studies. In addition, the relatively substantial literature on the reproductive physiology of sheep facilitates the design and interpretation of experiments.

This review will address some issues that may be important for studies of this type and will highlight a few, key, recent findings. Evidence from various species indicates that programming of development and subsequent physiology involves many different factors, including, for example, nutrition (Gunn et al., 1995) and high temperature stress (Colbrough, 1985). These effects are likely to be mediated, at least in part, through endogenous endocrine influences (Ford and Klindt, 1989). The involvement of endocrine signals also means that endocrine-disrupting compounds (EDC) present in the environment can also affect development (Sharpe et al., 1995; Toppari et al., 


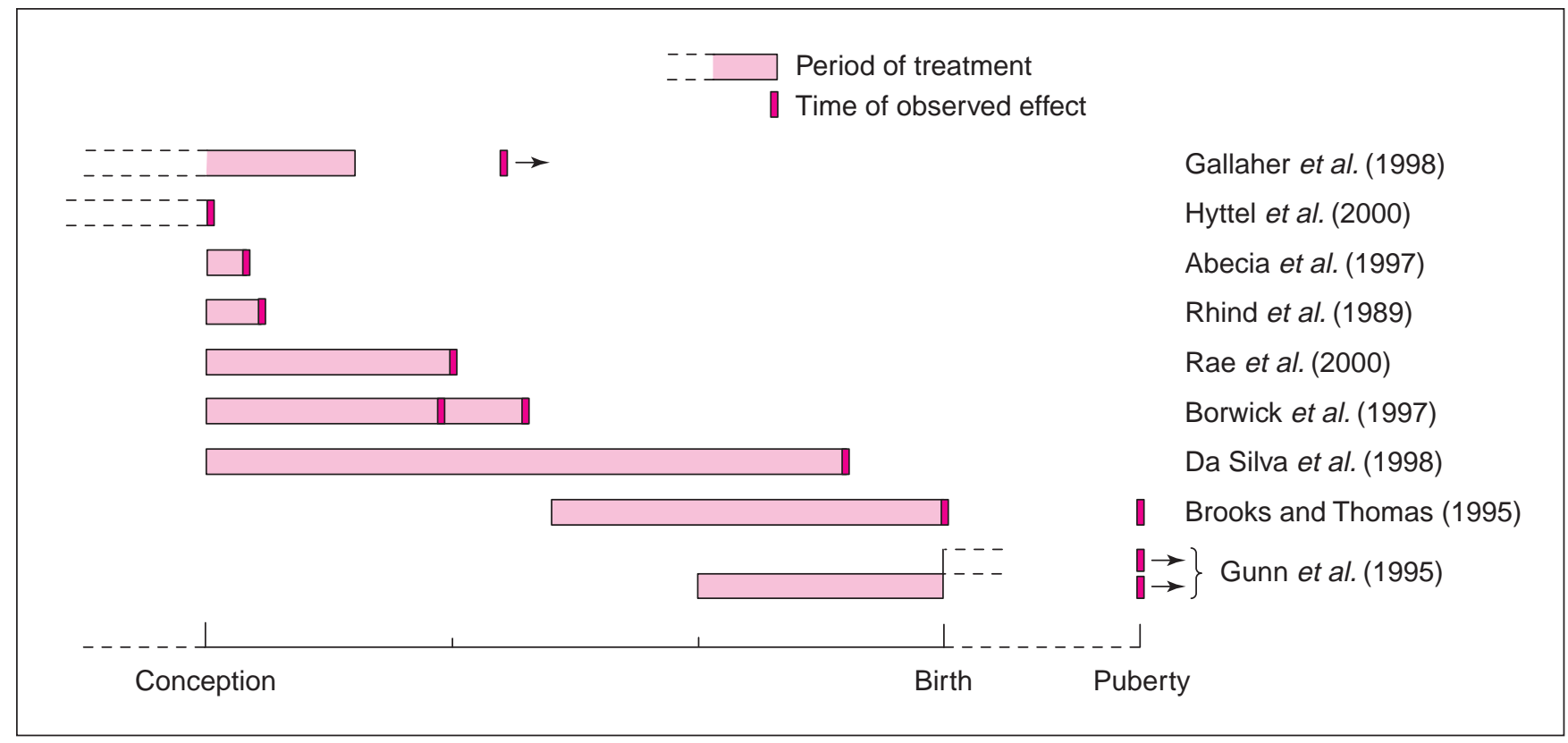

Fig. 1. Periods of development in sheep, cattle and pigs during which nutritional manipulations have been applied (light pink) and stages at which effects on structure or function of the reproductive system have been identified (dark pink).

1996; Crisp et al., 1998). Thus, it is likely that adult reproductive performance reflects the combined effects of multiple factors as diverse as nutrition, stress and EDC exposure, during prenatal development.

The economic significance of nutrition in domestic animal productivity has meant that a relatively large research effort has gone into this potential determinant of fetal programming and so many examples are drawn from these studies.

\section{When does programming occur?}

\section{Critical windows of development}

The available evidence indicates that the effects of early life nutrition on subsequent reproductive capacity may be exerted over a range of developmental stages (Fig. 1). Some of the first indications of an effect of undernutrition on the fetus were derived from the observation of an association between rearing environment, and therefore nutritional state, and lifetime reproductive performance (Gunn et al., 1972; Gunn, 1977; Allden, 1979). Subsequent studies were designed to identify the critical periods of development and were frequently concentrated on periods of maximum demand for nutrients during which, in practice, nutritional deficiencies might be considered most likely to occur, for example, during late pregnancy and early lactation.

In one large-scale and long-term study, involving nearly 500 Scottish Blackface ewes studied over 3 breeding years, Gunn et al. (1995) demonstrated a significantly higher incidence of multiple births in ewes born to dams given supplementary feed during pregnancy $(0.54$ versus 0.43$)$ or lactation (0.57 versus 0.43 ) when compared with unsupplemented controls. From this study, it may be concluded that undernutrition during early postnatal life influences subsequent reproductive function. However, it is not clear from the study whether this is the most critical period of development with respect to the programming of future performance. This study also indicates effects of prenatal nutrition, presumably mediated through the placenta. At present, there is little additional direct evidence to support these observations because of the high cost of conducting these experiments. However, the highly controlled studies of Da Silva et al. (1998) have shown that severe, placentally mediated nutritional restriction can affect development of the fetal hypothalamic-pituitary-gonadal axis adversely and delay the onset of puberty (Da Silva et al., in press), indicating that effects exerted on the developing fetus can be expressed at least as late as the onset of puberty.

Epidemiological studies of humans have shown that intrauterine nutrition is related to the incidence of certain chronic conditions in the offspring in middle age (Barker, 1992, 1994). More recent analyses of the Dutch famine birth cohort (Lumey, 1998) showed no relationship between fetal undernutrition and subsequent fertility, but there was an increased risk of still-birth and perinatal death among the offspring of women exposed to famine in the third trimester of pregnancy.

Undernutrition during early stages of fetal development might be expected to be relatively unimportant because the nutrient requirements for the growth and maintenance of fetuses during the first half of pregnancy are relatively low, as is indicated by the fact that $75 \%$ of the growth of sheep 
fetuses occurs during the last 6 weeks of gestation (Robinson et al., 1977). Thus, nutrient requirements for body growth during early gestation are clearly minimal and, indeed, are met during the first few weeks without the requirement for a placental delivery system. In fact, investigations of sheep fetuses between day 47 and day 65 of gestation have shown that undernutrition of the dam during the first 2 months of pregnancy results in delays in fetal ovarian structural development (Borwick et al., 1997) and changes in associated patterns of testicular steroidogenesis (Rae et al., 2000). Whether these effects are translated into effects on adult reproductive performance has yet to be determined.

Rhind et al. (1989) reported effects of undernutrition on growth before placental development has even begun. Undernutrition resulted in restriction of conceptus growth at as early as day 11 of gestation, several days before implantation. The length of the conceptus was significantly shorter $(\leqslant 500$ versus $1400 \mu \mathrm{m}$ ) in ewes fed $50 \%$ of live weight maintenance requirements than it was in those fed 1.5 times requirements. Although there was no significant difference in the size of the conceptus in ewes fed a reduced diet from 2 weeks before mating compared with ewes fed from mating, there was a trend towards a further reduction in length of conceptus in ewes that had been subjected to the pre-mating restriction (370 versus $500 \mu \mathrm{m}$ ), indicating a possible effect on conceptus development of the longer period of undernutrition. Similar effects have been reported at day 8 of pregnancy in undernourished ewes (Abecia et al., 1997). The effect of this restriction on the differentiation and development of the gonadal tissues, if any, remains to be determined but it seems likely that embryos at this stage of development are vulnerable to nutrient restriction.

Expression of maternal RNA and development of very early cattle embryos (containing fewer than 16 cells) are influenced adversely by an abnormal environment (culture medium) (Hyttel et al., 2000), indicating that embryos at this stage of development, in vivo, may be susceptible to changes in uterine environment such as those associated with undernutrition of the dam.

Studies of pig embryos produced by oocyte maturation in vitro and cattle embryos produced by nuclear transfer from morulae produced in vitro have shown an increased frequency of abnormalities in gene activation (Hyttel et al., 2000). These findings indicate that the developmental processes are altered by incubations in culture medium and that the effects of factors such as nutrition on embryonic and fetal development may be exerted through changes in the environment of the developing oocyte, that is, programming effects may extend as far back as the pre-conception stages.

Further evidence of very early programming is provided by the results of investigations of the adverse effects of heat stress in cattle (Putney et al., 1989); these studies showed that exposure of heifers to high temperatures for a few hours during early oestrus was associated with a reduction in embryo quality at day 7 after insemination. These observations are consistent with earlier reports of increased embryo wastage in heat-stressed cattle (Dunlap and Vincent, 1971; Gwazdauskas et al., 1973) and sheep (Dutt, 1963) and indicate that the normal pattern of embryonic development can be altered by brief adverse environmental influences at a critical window of development. More detailed studies of this phenomenon (Edwards and Hansen, 1996; Edwards et al., 1997; Chandolia et al., 1999) indicate that embryos have the capacity to respond to environmental influences such as heat shock by synthesizing protective heat shock proteins through newly activated mRNA transcription, as early as at the two-cell stage. Subsequent development is affected more severely by heat stress at the two-cell stage than at the four-cell or eight-cell stages because of the absence of protective proteins at or before this stage. Thus, normal programming is more likely to be compromised by adverse environmental influences at this very early stage than at later stages.

\section{Delayed responses}

Gallaher et al. (1998) showed that effects exerted during one period of development can impinge on responses to environmental factors during another, later, period. They observed that maternal undernutrition of ewes from 60 days before conception to 30 days after conception had no effect during later gestation on concentrations of insulin-like growth factors (IGFs) or their binding proteins (IGFBPs). However, when a second, additional window of undernutrition was applied during the third trimester, there was a significantly greater reduction in fetal plasma IGFBP-3 and IGF-I concentrations in fetuses that had been underfed at the earlier time. These results indicate that the observed effects of programming may not be attributable to effects exerted at only a single stage of pregnancy but may represent a response to multiple, interacting influences.

In view of such observations, care must be exercised when interpreting data from epidemiological human studies, particularly of humans in which details of previous nutritional regimens may be imperfectly defined. In a number of these studies, birth weight was used as an index of diet during human pregnancy. However, as noted by Lumey (1998), long-term effects of undernutrition may occur without apparent birth weight effects. Indeed, undernutrition effects may be absent even in cases of reduced birth weight (Lumey 1998) because the critical window of development occurs before the effects on fetal mass are expressed.

\section{Conclusions}

Collectively, this series of experiments conducted over several decades, using techniques ranging from simple weighing and body condition scoring to molecular biology, has shown that undernutrition of the dam can modify the development of embryos, fetuses and young animals, and may even exert effects before conception. Understanding of the mechanisms through which these effects are expressed 


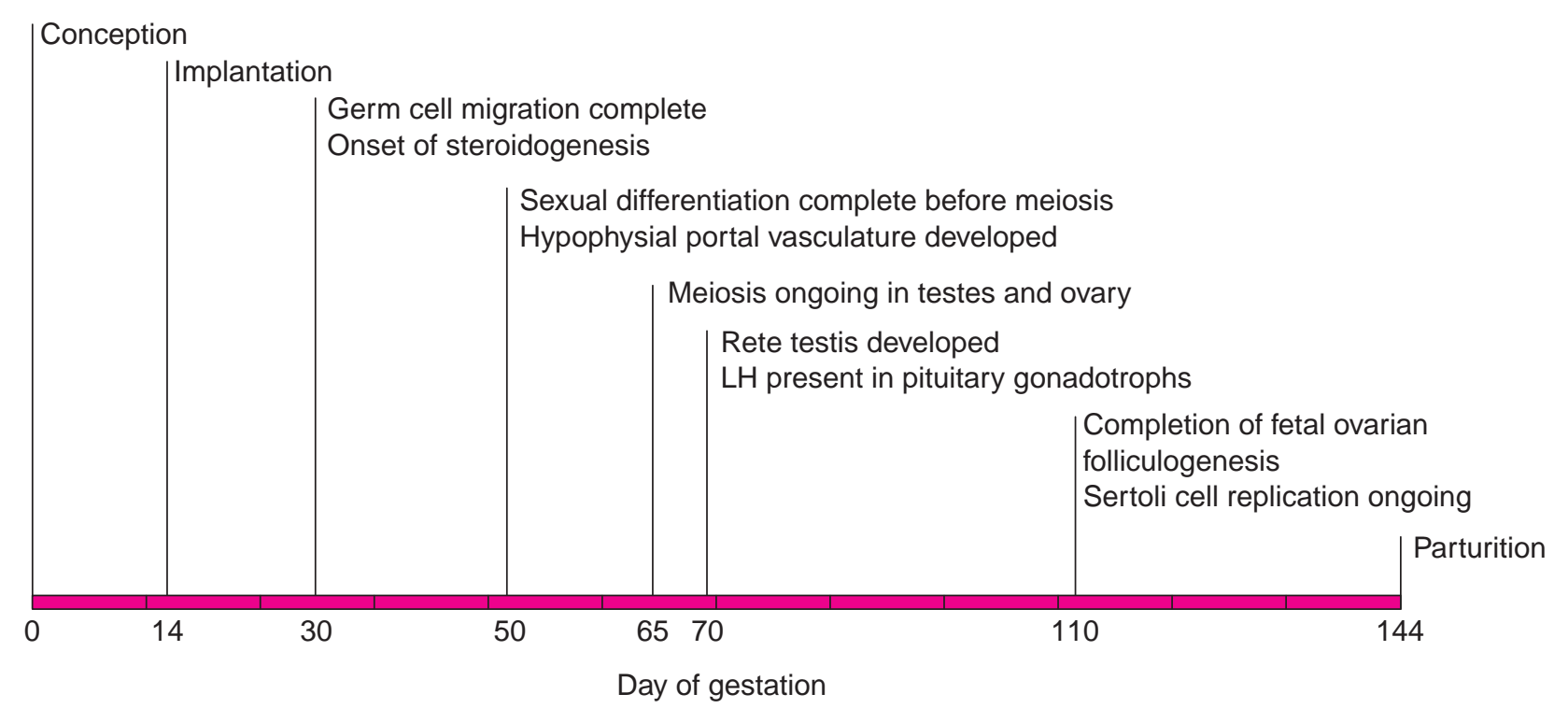

Fig. 2. Key stages in the ontogeny of the gonad of sheep fetuses.

remains poor. However, consideration of potential mediators, of the sites and mechanisms of action, and of the critical stages of fetal development may highlight appropriate areas for future research.

\section{What are the critical stages of development for fetal programming of the reproductive system?}

It is apparent from the previous section that there is potential to manipulate embryo and fetal development at many different stages. Nevertheless, a consideration of the stages of gestation at which tissues become differentiated and at which specific developmental processes occur can be instructive with respect to the times at which programming is likely to occur. Clearly, if undernutrition is applied for a period of gestation before a certain organ, cell type or receptor has developed, it cannot be affected directly by the treatment. However, it may be affected by previously induced changes in precursor cells or tissues.

Consideration of the ontogeny of mammals, again using the sheep as an example, reveals a number of potentially significant stages of development (Fig. 2). Clearly, any effect of undernutrition on the process of tissue differentiation, gonad formation and the establishment of associated enzyme systems is likely to have a fundamental effect on the subsequent function of these organs and so this must be considered to be a critical stage of development. In sheep, a transient period of steroid synthesis occurs in the fetal ovary between approximately day 35 and day 55 of gestation (Mauleon et al., 1977). The precise function of this transient phenomenon is unknown but it broadly coincides with the onset of meiosis in the germ cells (Mauleon and Mariana,
1977). A further potentially critical window of development in the female fetus is the period up to the end of folliculogenesis (approximately 110 days in sheep; Mauleon, 1973), beyond which time the number of ovarian follicles cannot be modified.

In male fetuses, critical windows are less clearly defined. Seminiferous cords are present by about day 35 and by day 70 the rete testis is organized in the centre of the testis and stains intensively for androgen receptor (Sweeney et al., 1997). Sertoli cell replication continues throughout fetal life and extends to about 6-8 weeks into post-natal life in sheep (Sharpe, 1994) and so may be susceptible to the effects of undernutrition or other environmental factors throughout this period.

In fetuses of both sexes, the development of the hypothalamic-pituitary axis and the associated synthesis of gonadotrophins is potentially sensitive to nutritional and other influences. In all vertebrate species studied, the main population of $\mathrm{GnRH}$ neurones originates outside the brain (in the olfactory placode epithelium), and migration into the brain, axonal growth and maturation to adult morphology occur during the first half of gestation. In the sheep fetus, the $\mathrm{GnRH}$ neuronal systems develop between about day 35 and day 85 of gestation, at which point they are very similar to the GnRH neuronal systems of adults (Caldani et al., 1995). Fetal undernutrition has been shown to affect the general maturation of neurocircuitry and axonal growth adversely (Sima and Sourander, 1978; Sharma et al., 1987; Morgane et al., 1993) but there is currently no information on the effects of undernutrition on the $\mathrm{GnRH}$ neuronal system. However, in sheep, $\alpha$ and $\beta$ subunits are not present in the pituitary gland, in combination, until day 70 (LH) or day 
100 (FSH) of a 145 day gestation (Thomas et al., 1993). Thus, fetal programming through changes in these factors cannot occur before the second half of gestation.

After birth, most fundamental programming of reproductive function has probably been completed. However, the observations of Gunn et al. (1995) and Rhind et al. (1998a) indicate that nutritional regimen in early life can influence subsequent reproductive performance in females. Since the developmental processes are largely complete by this time, it is possible that the observed effects on reproductive performance represent effects of postnatal nutrition on the processes of follicle recruitment, as indicated by a reduction in ovulation rate 6 months after a period of undernutrition in adult ewes (Fletcher, 1974). Oocyte quality may also be affected. Equivalent effects may occur in males but, to date, these have not been investigated.

The effects of prenatal programming on reproductive performance may not end with the present generation. Environmental factors can alter gene activity so that the factor they control is modified in the subsequent generation in an apparently Larmarckian manner. In a study of laboratory fruit flies, an external influence (brief heat shock) resulted in the activation of a gene that resulted in the flies having red eyes, a trait that was passed to the next generation (Cavalli and Paro,1998).

Evidence is emerging of similar transgenerational transfer of the effects of undernutrition. Lumey (1992), in a followup study of babies born to women exposed to the Dutch famine of 1944-1945, found that children born to mothers who had been undernourished as fetuses had birth weights $6 \%$ lower than those born to pre-famine controls. These results indicate that undernutrition modifies gene expression not only in the individual fetus but also in its offspring and perhaps in successive generations.

Although potentially important periods of development can be identified relatively easily, it is impossible to assess the relative importance of each of these windows of development without detailed studies of the effects of different factors on the developmental process and of the consequences of such effects, if any, in later life.

\section{What physiological systems are involved in fetal programming and how are they affected?}

\section{What are the signals?}

Although some environmental influences, such as EDCs, may act directly on the target organs to induce endocrine, cellular, structural and gene expression alterations, it is likely that the effects of many factors, including nutrition and social and climatic stresses, are exerted through changes in endocrine profiles. Despite extensive research into the effects of many different factors on endocrine profiles, they remain poorly understood and a detailed review of the topic is beyond the scope of this review. Briefly, hormones that seem most likely to have a direct, pivotal role in the mediation of environmental or nutritional effects on the developing fetus include insulin, IGFs (and their associated binding proteins), thyroid hormones (particularly triiodothyronine $\left(T_{3}\right)$ ) and leptin. Profiles of some or all of the hormones listed can be modified by nutritional state (insulin: Bassett, 1974; IGF-I and $\mathrm{T}_{3}$ : Rhind et al.,1998b; leptin: Hardie et al., 1996) and climatic factors $\left(\mathrm{T}_{3}\right.$ : Sterling and Lazarus, 1977; leptin: Hardie et al., 1996) and the thyroid hormones can be altered by certain environmental endocrine disruptors (Hansen, 1998). Furthermore, preliminary data indicate that maternal undernutrition reduces not only maternal but also fetal $\mathrm{T}_{3}$ concentrations (M. T. Rae, S. M. Rhind and A. N. Brooks, unpublished).

The abovementioned hormones are known to have direct or indirect effects on gonads (insulin and IGF-I: Gong et al., 1991; leptin: Clarke and Henry, 1999; $\mathrm{T}_{3}$ : Chandrasekhar et al., 1985; Shi and Barrell, 1992) and are present and active in the brain (insulin: Schwartz et

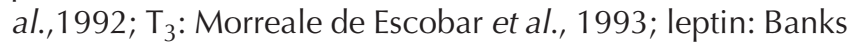
et al., 1996; IGF-I: Miller et al., 1998), indicating that they each have the potential to mediate the effects of environmental factors and to influence programming of any of the target reproductive organs in the fetus.

Circulating concentrations of other hormones and metabolites are almost certainly involved in the signalling process but they probably have a less crucial, possibly permissive role with respect to reproductive organ function. For example: growth hormone and cortisol, which are involved in the regulation of nutrient availability but probably exert their effects through interaction with insulin and IGF (Trenkle, 1981); glucose, which is essential for neural function although, in ruminants, circulating concentrations are poorly related to changes in rates of utilization (Russel, 1978); urea, the product of amino acid metabolism in ruminants, circulating concentrations of which, when generated in excess amounts, are not related to protein intake (Sykes, 1978); non-esterified fatty acids, which exhibit marked variations associated with stress or food intake (Russel, 1978) making them of questionable relevance as a long-term signal.

In addition, some environmental factors, particularly EDCs, are known to exert their effects on the reproductive system much more directly either through the oestrogen receptors or through receptor-independent effects on enzyme systems (McLachlan et al., 1984; Navas and Segner, 1998).

Measures of these putative signals should be incorporated into future research into the mechanisms by which environmental factors affect fetal programming. In particular, there is a need to measure hormones and metabolites in the developing fetus and to determine how they are influenced by changes in maternal physiological state.

\section{Which physiological systems are altered?}

Programming of reproductive capacity in the fetus can be achieved through changes in either the hypothalamus- 


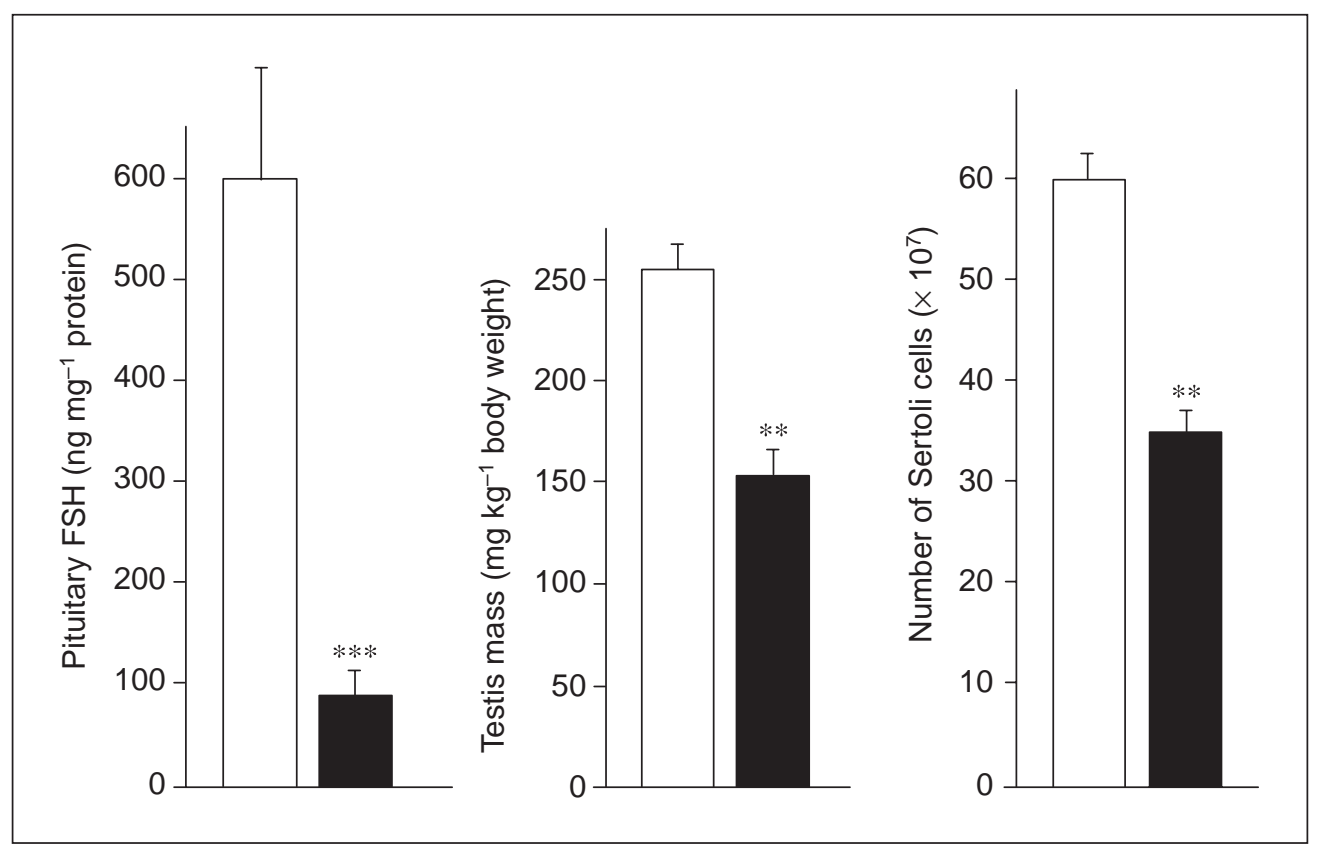

Fig. 3. Mean ( $\pm \mathrm{SE}$ ) pituitary FSH concentrations ( $\mathrm{ng} \mathrm{mg}^{-1}$ protein), testis mass ( $\mathrm{mg} \mathrm{kg}^{-1}$ body weight) at birth and numbers of Sertoli cells per testis in lambs treated with the GnRH agonist, buserelin, from day 70 of gestation until birth (ם) and in control lambs $(\square)$. ${ }^{* *} P<0.01$; ${ }^{* * *} P<0.001$.

pituitary gland or through the gonads. The stage of fetal development at which each of these organs is susceptible to environmental or nutritional influences is not necessarily the same. Similarly, the effects in the adult animal of alterations in the function of these organs in the fetus may differ with both the organ affected and the age of the animal. Measurements of the effects of nutritional or other manipulations of the fetus, to date, have not been linked to effects on the reproductive performance of the adult.

\section{Nutritional programming of the hypothalamus-pituitary}

Initial studies of fetal programming in relation to reproductive capacity centred on the hypothalamus, since the critical role in gonadal function of secretion of $\mathrm{GnRH}$, and associated release of $\mathrm{LH}$ from the pituitary, was well known. However, effects of exogenous factors on fetal hypothalamic function and, in turn, on gonadotrophin secretion and gonadal function, can be expressed only when the necessary neurones and associated receptors have developed.

The ontogeny of fetal hypothalamic function has been studied in sheep by the application, from day 70 of gestation, of the GnRH agonist, buserelin, to inhibit fetal gonadotrophin secretion (Brooks and Thomas, 1995; Brooks et al., 1996). Brooks and Thomas (1995) demonstrated the essential role of pulsatile LH secretion by the fetal pituitary for the normal development of the testis; blocking $\mathrm{GnRH}$ and $\mathrm{LH}$ pulses with buserelin resulted in a significant reduction in pituitary FSH concentrations, a 40\% reduction in testis mass at birth and a similar reduction in the numbers of Sertoli cells (Fig. 3). The reduction in testis mass was associated with reduced testosterone production after puberty, indicating that reproductive function may have been permanently impaired by the treatment during pregnancy.

When treatment with buserelin was restricted to the period between day 70 and day 110 of a 145 day pregnancy, there was no reduction in testis mass (Brooks and Thomas, 1995; Brooks et al., 1996). Taken together, these results indicate that testis development is related to $\mathrm{GnRH}$ and LH pulse frequency and that there is a critical window in late pregnancy, after the development of $\mathrm{GnRH}$ neurones, which is completed at approximately day 85 of gestation.

There are no published reports of the effects of nutrition on gonadotrophin profiles during late pregnancy. However, indirect evidence of pituitary modulation by nutrition during early pregnancy is provided by the studies of Hawkins et al. (1999) who reported that a small reduction $(15 \%)$ in feed intake during the first half of gestation in ewes resulted in a reduction in pituitary responsiveness to corticotrophin-releasing hormone or arginine vasopressin during the second half of gestation. There were no differences in fetal size or organ mass at the time of differential pituitary sensitivity.

\section{Nutritional programming of the gonads}

Although observations of effects on reproductive capacity of late pregnancy nutrition, or exposure to other environmental factors, may be explained in terms of effects 
on gon-adotrophin profiles, clearly this is not the mechanism by which early pregnancy effects are mediated since the gonadotrophic-gonadal axis is not in place before about day 70 of gestation in sheep. Thus, it is likely that the effects are mediated via direct effects on the gonads, that is, independently of hypothalamic-pituitary function and gonadotrophin secretion. This conclusion has led to assessment of the effects of undernutrition during early pregnancy on the histology and steroidogenic capacity of fetal gonads.

In a study of female fetuses, Borwick et al. (1997) reported minimal, non-significant reductions in fetal ovarian mass at days 47 and 62 of gestation in response to underfeeding at a rate of $50 \%$ of the ration required for maintenance of live weight. However, in a separate study, a significant reduction in ovarian mass was recorded at day 50 of gestation in animals fed restricted rations from the time of mating or from the time of ovarian development at about day 30 of gestation (M. T. Rae, A. N. Brooks and S. M. Rhind, unpublished).

Histological assessment of the day 47 ovaries (Borwick et al., 1997) revealed significantly more oocytes in fetuses from nutritionally restricted ewes (fed $50 \%$ of live weight maintenance requirements) than in fetuses from adequately fed ewes (fed $150 \%$ of live weight maintenance requirements). This finding has been interpreted to mean that the normal processes of oogonial degradation that occur at about this time and cause a reduction in oocyte number are delayed in undernourished fetuses (Borwick et al., 1997). Indeed, subjective assessment of the ovaries indicated that there was a decrease in phagocytosis of oocytes in the restricted ovaries. In view of the fact that ovarian production of oestradiol at this time may affect the onset of meiosis (Shemesh, 1980), it is noteworthy that there were no treatment differences in the steroidogenic capacity of the ovaries at this time.

Mean numbers of oocytes at day 62 were also higher in the fetuses derived from undernourished ewes, indicating delayed development (Borwick et al., 1997). Furthermore, in the ovaries of fetuses from feed-restricted ewes, there were significantly more germ cells entering the initial stages of meiosis at this time, compared with control animals in which a larger proportion of germ cells had completed this process and entered meiotic arrest (Borwick et al., 1997).

In male fetuses, no structural differences (seminiferous tubule diameter, tubule number, testicular mass) or differences in number of Sertoli, peritubular myoid and Leydig cells were recorded in response to undernutrition (dams fed 50 versus $100 \%$ of live weight maintenance) during all or part of the first 50 days of gestation (Rae et al., 2000).

More detailed studies showed that fetal plasma testosterone concentrations were significantly increased in fetuses from undernourished dams compared with controls (Rae et al., 2000); similar, stress-induced perturbations in testosterone secretion in fetal rats are associated with altered sexual behaviour in adult life (Ward and Weisz, 1980). The presence of steroid acute regulatory protein (StAR) and $\mathrm{P}_{450} \mathrm{C} 17 \alpha$-hydroxylase $\mathrm{c} 17,20$ lyase $(\mathrm{C} 17 \mathrm{OH})$ was demonstrated in all testes using immunohistochemistry (Rae et al., 2000) at both day 50 and day 65 of gestation, and in situ hybridization showed that expression of StAR was also higher in fetuses from undernourished ewes than in fetuses from control ewes. A similar, non-significant trend was also recorded in the expression of $\mathrm{C} 17 \mathrm{OH}$, indicating that the effect of undernutrition on fetal testosterone concentrations is expressed through increased expression of these steroidogenic systems.

Since the above measurements were made at a stage before the development of a functional pituitary-gonadal system, the observed responses were gonadotrophinindependent. Similar observations in rats have also shown that onset of testicular steroidogenesis is independent of $\mathrm{LH}$ (Majdic et al., 1998). In view of the pivotal role of testosterone and its metabolites in the development of the male phenotype and neural development, such perturbations may be of importance in the development of normal male function.

In the normally developing gonad, each stage of development is associated with a particular hormonal milieu and when development is delayed or the milieu is altered, as in the fetuses of undernourished ewes, the stage of development and the milieu become asynchronous. The physiological consequences of this asynchrony are not known, but it is possible that it subsequently exacerbates the adverse effect of undernutrition on development.

\section{Endocrine disruptors and programming of the reproductive axis}

The importance for adult reproductive performance of effects on fetal development has been highlighted by studies of the effects of EDCs on reproductive capacity in adults. Although much of the interest in the topic stems from concerns about male human fertility as a result of exposure to EDCs (Toppari et al., 1996; Crisp et al., 1998), it is studies on rodents and ruminants that have produced empirical evidence of adverse effects on the developing gonad. Sharpe et al. (1998) showed that treatment of fetal rats with diethylstilboestrol resulted in a reduction in testicular size and in the number of Sertoli cells that developed. This reduction in the number of Sertoli cells was permanent and resulted in a reduction in sperm production at maturity. Similarly, Lee (1998) reported dose-dependent disruptive effects of environmental concentrations (0.08-0.8 $\mathrm{mg} \mathrm{kg}^{-1}$ body weight) of the EDC nonylphenol administered postnatally to male rat pups. These pups also exhibited reductions in testis size and associated changes in structure but the effects were observed only when the treatments were applied before 13 days of age, that is, there was a critical window of development after which the reproductive system was no longer sensitive to the EDC. Sweeney et al. (2000) showed that exposure of pregnant ewes to moderately high doses ( $1 \mathrm{mg} \mathrm{kg}^{-1}$ day $\left.^{-1}\right)$ of octylphenol or diethylstilboestrol $\left(0.5 \mu \mathrm{g} \mathrm{kg}^{-1}\right.$ day $\left.^{-1}\right)$ from day 70 of gestation caused a significant reduction in the number of $\mathrm{FSH} \beta$-immunopositive 
pituitary cells and reduced FSH $\beta$ mRNA expression in the pituitary glands of their lambs. Testis mass and number of Sertoli cells at birth were also significantly reduced.

Collectively, these studies indicate that the effects of EDCs are expressed at various stages of development and are exerted through action on both the hypothalamicpituitary system and the gonads.

\section{Thermal stress and programming of the reproductive axis}

Although there is clear evidence of effects of early life programming by nutrition and EDCs on adult reproductive physiology, the effects of thermal stress are less well defined, perhaps because in many cases the fetus fails to survive beyond a few weeks of age. Effects of high body temperature around the time of oestrus and oocyte maturation on embryo development to day 7 of gestation have been reported (Putney et al., 1989), but there have been no controlled studies to assess effects on subsequent hypothalamic-pituitary-gonadal development or on adult reproductive function.

\section{Conclusions}

On the basis of data obtained over many decades, it is clear that environmental factors can greatly alter development of fetal hypothalamic-pituitary and gonadal structure and physiology, including numbers of cells, enzyme systems and hormone output. These effects are particularly marked during the period of rapid gonadal development and differentiation. The importance of the observed delays in development of the gonadal tissues during the first half of pregnancy, with respect to subsequent lifetime reproductive capacity, remains uncertain.

There is a need to determine which of the effects on early and late fetal development already recorded result in reductions in lifetime reproductive performance and to identify stages of development that are the most critical in the determination of adult reproductive capacity. There is also a need to extend studies to investigate the effects of different components of feed inputs (for example, protein and other specific nutrients) and into the metabolic or hormonal mechanisms by which maternal status is signalled to the fetus. Finally, there is a need to investigate potential synergism and antagonism between the actions of EDCs, stress and nutrition at each stage of gestation. This work will be challenging but will provide much needed insight into the roles of these factors in fetal programming and their effects on reproductive performance in the adult.

\section{References}

Key references are identified by asterisks.

Abecia JA, Lozano JM, Forcada F and Zarazaga L (1997) Effect of level of dietary energy and protein on embryo survival and progesterone production on day 8 of pregnancy in Rasa Aragonesa ewes Animal Reproduction Science 48 209-218

Allden WG (1979) Undernutrition of the Merino sheep and its sequelae 5. The influence of severe growth retardation during early post-natal life on reproduction and growth in later life Australian Journal of Agricultural Science 30 939-948

Banks WA, Kastin AJ, Huang W, Jaspan JB and Maness LM (1996) Leptin enters the brain by a saturable system independent of insulin Peptides $\mathbf{1 7}$ 305-311

Barker DJP (1992) Fetal and Infant Origins of Adult Disease British Medical Journal Publishing Group, London

Barker DJP (1994) Mothers, Babies and Diseases in Later Life British Medical Journal Publishing Group, London

Bassett JM (1974) Diurnal patterns of plasma insulin, growth hormone, corticosteroid and metabolite concentrations in fed and fasted sheep Australian Journal of Biological Science 27 167-181

*Borwick SC, Rhind SM, McMillen SR and Racey PA (1997) Effect of undernutrition of ewes from the time of mating on fetal development in mid gestation Reproduction, Fertility and Development 9 711-715

Brooks AN and Thomas GB (1995) Ontogeny and function of the pituitary-gonadal axis during fetal development in sheep Reproduction in Domestic Animals 30 158-162

*Brooks AN, Hagan DM, Sheng C, McNeilly AS and Sweeney T (1996) Prenatal gonadotrophins in sheep Animal Reproduction Science 42 471-481

Caldani M, Antoine M, Batailler M and Duittoz A (1995) Ontogeny of $\mathrm{GnRH}$ systems Journal of Reproduction and Fertility Supplement $\mathbf{4 9}$ 147-162

Cavalli G and Paro R (1998) The Drosophila Fab-7 chromosomal element conveys epigenetic inheritance during mitosis and meiosis Cell $\mathbf{9 3}$ 505-518

Chandolia RK, Peltier MR, Tian W and Hansen PJ (1999) Transcriptional control of development, protein synthesis and heat-induced heat shock protein 70 synthesis in 2-cell bovine embryos Biology of Reproduction 61 1644-1648

Chandrasekhar Y, Holland MK, D'Occhio MJ and Setchell BP (1985) Spermatogenesis, seminal characteristics and reproductive hormone levels in mature rams with induced hypothyroidism and hyperthyroidism Journal of Endocrinology 105 39-46

Clarke IJ and Henry BA (1999) Leptin and reproduction Reviews of Reproduction 4 48-55

Colbrough RI (1985) Stress and fertility: a review Onderstepoort Journal of Veterinary Science $\mathbf{5 2}$ 153-156

*Crisp TM, Clegg ED, Cooper RL, Wood WP, Anderson DG, Baetcke KP, Hoffman JL, Morrow MS, Rodier DJ, Schaeffer JE, Touart LW, Zeeman MG and Patel YM (1998) Environmental endocrine disruption: an effects assessment and analysis Environmental Health Perspectives $\mathbf{1 0 6}$ Supplement 111-56

Da Silva P, Aitken RP, Brooks AN, Rhind SM and Wallace JM (1998) Perturbed pituitary gonadotrophin gene expression and gonadal development in growth restricted fetal lambs at day 128 of gestation Journal of Reproduction and Fertility Abstract Series 2210

Da Silva P, Aitken RP, Rhind SM, Racey PA and Wallace JM Placentally mediated fetal growth restriction influences the onset of puberty in male but not in female lambs Reproduction 122 (in press)

Dunlap SK and Vincent CK (1971) Influence of postbreeding thermal stress on conception rate in beef cattle Journal of Animal Science 32 1216-1218

Dutt RH (1963) Critical period for early embryo mortality in ewes exposed to high ambient temperature Journal of Animal Science 22 713-719

Edwards JL and Hansen PJ (1996) Elevated temperature increases heat shock protein 70 synthesis in bovine two-cell embryos and compromises function in maturing oocytes Biology of Reproduction $\mathbf{5 5}$ 340-346

Edwards JL, Ealy AD, Monterroso VH and Hansen PJ (1997) Ontogeny of temperature-regulated heat shock protein 70 synthesis in preimplantation bovine embryos Molecular Reproduction and Development 48 25-33

Fletcher IC (1974) An effect of previous nutritional treatment on the ovulation rate of Merino ewes Proceedings of the Australian Society of Animal Production 10 261-264

Ford JJ and Klindt J (1989) Sexual differentiation and the growth process. In Animal Growth Regulation pp 317-336 Eds DR Campion, GJ Hausman and RJ Martin. Plenum Publishing Corporation, New York 
Gallaher BW, Breier BH, Keven CL, Harding JE and Gluckman PD (1998) Fetal programming of insulin-like growth factor (IGF)-1 and IGF-binding protein-3: evidence for an altered response to undernutrition in late gestation following exposure to preconceptual undernutrition in the sheep Journal of Endocrinology 159 501-508

Gong JG, Bramley TA and Webb R (1991) The effect of recombinant bovine somatotropin on ovarian function in heifers: follicular populations and peripheral hormones Biology of Reproduction 45 941-949

*Gunn RG (1977) The effects of two nutritional environments from 6 weeks prepartum to 12 months of age on lifetime performance and reproductive potential of Scottish Blackface ewes in two adult environments Animal Production 25 155-164

Gunn RG, Doney JM and Russel AJF (1972) Embryo mortality in Scottish Blackface ewes as influenced by body condition at mating and by postmating nutrition Journal of Agricultural Science, Cambridge 79 19-25

Gunn RG, Sim D and Hunter EA (1995) Effects of nutrition in utero and in early life on the subsequent lifetime reproductive performance of Scottish Blackface ewes in two management systems Animal Science $\mathbf{6 0}$ 223-230

Gwazdauskas FC, Thatcher WW and Wilcox CJ (1973) Physiological, environmental, and hormonal factors at insemination which may affect conception Journal of Dairy Science $\mathbf{5 6} 873-877$

Hansen L (1998) Stepping backward to improve assessment of PCB congener toxicities Environmental Health Perspectives 106 171-189

Hardie LH, Rayner DV, Holmes S and Trayhurn P (1996) Circulating leptin levels are modulated by fasting, cold exposure and insulin administration in lean but not Zucker $(\mathrm{fa} / \mathrm{fa}$ ) rats as measured by ELISA Biochemical and Biophysical Research Communications 223 660-665

Hawkins P, Steyn C, McGarrigle HHG, Saito T, Ozak T, Stratford IL, Noakes DE and Hanson MA (1999) Effect of maternal nutrient restriction in early gestation on development of the hypothalamic-pituitaryadrenal axis in fetal sheep at 08-09 of gestation Journal of Endocrinology 163 553-561

*Hyttel P, Laurincik J, Viuff D, Fair T, Zakhartchenko V, Rosenkranz C, Avery B, Rath D, Niemann H, Thomsen PD, Schellander K, Callesen H, Wolf E, Ochs RL and Greve T (2000) Activation of ribosomal RNA genes in pre-implantation cattle and swine embryos Animal Reproduction Science 60-61 49-60

Lee PC (1998) Disruption of male reproductive tract development by administration of the xenoestrogen, nonylphenol, to male newborn rats Endocrine 9 105-111

*Lumey LH (1992) Decreased birthweights in infants after maternal in utero exposure to the Dutch famine of 1944-1945 Paediatric and Perinatal Epidemiology 6 240-253

Lumey LH (1998) Reproductive outcomes in women prenatally exposed to undernutrition: a review of findings from the Dutch famine birth cohort Proceedings of the Nutrition Society 57 129-135

McLachlan JA, Korach KS, Newbold RR and Degen GH (1984) Diethylstilbestrol and other estrogens in the environment Fundamental and Applied Toxicology 4 686-691

Majdic G, Saunders PTK and Teerds KJ (1998) Immunoexpression of the steroidogenic enzymes 3-beta hydroxysteroid dehydrogenase and $17 \alpha$ hydroxylase, C17,20 lyase and the receptor for luteinizing hormone $(\mathrm{LH})$ in the fetal rat testis suggests that the onset of Leydig cell steroid production is independent of $\mathrm{LH}$ action Biology of Reproduction $\mathbf{5 8}$ $520-525$

Mauleon P (1973) Kinetics of oogenesis in mammals Archives Anatomie Microscopie Morphologie Experimentation 56 125-150

Mauleon P and Mariana JC (1977) Oogenesis and folliculogenesis. In Reproduction in Domestic Animals Edn 3 pp 175-198 Eds HH Cole and PT Cupps. Academic Press, New York

Mauleon P, Bezard J and Terqui M (1977) Very early and transient $17 \beta$ estradiol secretion by the fetal sheep ovary Annales Biologie Animales Biochemie Biophysiques 17 399-401

Miller DW, Blache D, Boukliq R, Curlewis JD and Martin GB (1998) Central metabolic messengers and the effects of nutrition on gonadotrophin secretion in sheep Journal of Reproduction and Fertility $112347-356$

Morgane PJ, Austin-La France R, Bronzino J, Tonkiss J, Diaz-Cintra S,
Cintra L, Kemper T and Galler JR (1993) Prenatal malnutrition and the development of the brain Neuroscience Biobehaviour Reviews 17 $91-128$

Morreale de Escobar G, Obregon MJ, Calvo R and Escobar del Rey F (1993) Effects of iodine deficiency on thyroid hormone metabolism and the brain in fetal rats: the role of maternal transfer of thyroxin American Journal of Clinical Nutrition Supplement 57 280S-283S

Navas JM and Segner H (1998) Antiestrogenic activity of anthropogenic and natural chemicals Environmental Science and Pollution Research $\mathbf{5}$ 75-82

Putney DJ, Mullins S, Thatcher WW, Drost M and Gross TS (1989) Embryonic development in superovulated dairy cattle exposed to elevated ambient temperatures between the onset of estrus and insemination Animal Reproduction Science 19 37-51

Rae MT, Rhind SM, Kyle CK, Fowler PA, Miller DW and Brooks AN (2000) Maternal undernutrition during early pregnancy up-regulates fetal testicular steroidogenesis in sheep Journal of Reproduction and Fertility Abstract Series 25 Abstract 38

Rhind SM, McKelvey WAC, McMillen SR, Gunn RG and Elston DA (1989) Effect of restricted food intake, before and/or after mating, on the reproductive performance of greyface ewes Animal Production 48 149-155

Rhind SM, Elston DA, Jones JR, Rees JR, McMillen SR and Gunn RG (1998a) Effects of restriction of growth and development of Brecon Cheviot ewe lambs on subsequent lifetime reproductive performance Small Ruminant Research 30 121-126

Rhind SM, McMillen SR, Duff E, Hirst D and Wright S (1998b) Seasonality of meal patterns and hormonal correlates in red deer Physiology and Behaviour 65 295-302

Robinson JJ, McDonald I, Fraser C and McHattie I (1977) Studies on reproduction in prolific ewes I. Growth of the products of conception Journal of Agricultural Science, Cambridge 88 539-552

Russel AJF (1978) The use of measurements of energy status in pregnant ewes. In Blood Profiles in Animal Production, British Society of Animal Production Occasional Publication No. 1 pp 31-39 Ed. D Lister. BSAP, Milton Keynes

Schwartz MW, Figlewicz DP, Baskin DG, Woods SC and Porte D (1992) Insulin in the brain: a hormonal regulator of energy balance Endocrine Reviews 13 387-414

Sharma SK, Nayar U, Maheshwari MC and Singh B (1987) Effect of undernutrition on developing rat cerebellum. Some electrophysiological and neuromorphological correlates Journal of Neurological Sciences $\mathbf{7 8}$ $261-272$

Sharpe RM (1994) Regulation of spermatogenesis. In The Physiology of Reproduction pp 1363-1434 Eds E Knobil and JD Neill. Raven Press, New York

Sharpe RM, Fisher JS, Millar MR, Jobling S and Sumpter JP (1995) Gestational and lactational exposure of rats to xenoestrogens results in reduced testicular size and sperm production Environmental Health Perspectives 103 1136-1143

Sharpe RM, Atanassova N, McKinnell C, Parte P, Turner KJ, Fisher JS, Kerr JB, Groome NP, Macpherson S, Millar MR and Saunders PTK (1998) Abnormalities in functional development of the Sertoli cells in rats treated neonatally with diethylstilbestrol: a possible role for estrogens in Sertoli cell development Biology of Reproduction 59 1084-1094

Shemesh M (1980) Estradiol-17 $\beta$ biosynthesis by the early bovine fetal ovary during the active and refractory phases Biology of Reproduction 23 577-582

Shi ZD and Barrell GK (1992) Requirement of thyroid function for the expression of seasonal reproductive and related changes in red deer (Cervus elaphus) stags Journal of Reproduction and Fertility 94 251-259

Sima A and Sourander P (1978) The effect of pre- and postnatal undernutrition on axonal growth and myelination of central motor fibers. A morphometric study on rat cortico-spinal tract Acta Neuropathologica (Berlin) 26 15-18

Sterling K and Lazarus JH (1977) The thyroid and its control Annual Review of Physiology 39 349-371

Sweeney T, Saunders PTK, Millar MR and Brooks AN (1997) Ontogeny of anti-Müllerian hormone, 3ß-hydroxysteroid dehydrogenase and androgen 
receptor expression during ovine fetal gonadal development Journal of Endocrinology 153 27-32

*Sweeney T, Nicol L, Roche JF and Brooks AN (2000) Maternal exposure to octylphenol suppresses ovine fetal follicle-stimulating hormone secretion, testis size, and Sertoli cell number Endocrinology 141 2667-2673

Sykes AR (1978) An assessment of the value of plasma urea nitrogen and albumin concentrations as monitors of the protein status of sheep. In Blood Profiles in Animal Production, British Society of Animal Production Occasional Publication No. 1 pp 143-154 Ed. D Lister. BSAP, Milton Keynes

Thomas GB, McNeilly AS and Brooks AN (1993) Development of gonadotrophs and thyrotrophs in the female foetal sheep pituitary: immuno- cytochemical localization studies Journal of Neuroendocrinology $\mathbf{5}$ 157-161

Toppari J, Larsen JC, Christiansen P, Giwercman A, Grandjean P, Guillette LJ, Jegou B, Jensen TK, Jouannet P, Keiding N, Leffers H, McLachlan JA, Meyer O, Muller J, Meyts ER, Scheike T, Sharpe R, Sumpter J and Skakkebaek NE (1996) Male reproductive health and environmental xenoestrogens Environmental Health Perspectives 104 Supplement 4 $741-803$

Trenkle A (1981) Endocrine regulation of energy metabolism in ruminants Federation Proceedings 40 2536-2541

Ward IL and Weisz J (1980) Maternal stress alters plasma testosterone in fetal males Science 207 328-329 